\title{
MEANING OF ADJUSTMENT FOR WIFE WITH HUSBAND'S HAVE POLYGAMY
}

\author{
Hetty Anggraini
}

STKIP AL Islam Tunas Bangsa Bandar Lampung

\begin{abstract}
This study aims to discover the meaning of adjustments for the wife whose husband's polygamy. Subjects in this study were 3 people who were selected based techniques purposivitas with the characteristics of the subject, the woman who was the first wife of a polygamous husband, aged between 40-70 years, have children, have their own income, and age polygamous marriage a minimum of 3 years. The data in this study were collected through participant observation and in-depth interviews. To assess the validity of the data used triangulation method. This research is a qualitative approach to multi-case study. The results of this study indicate that the meaning of adjustment for wives whose husbands are polygamous through life with not much demand, thanks to the existing favors. Life lived at this time is the road to self-closeness to the Creator and the path of devotion to Allah Subhannahu Wa Ta'ala. Meaning of adjustments for the wife whose husband polygamous sourced from creative values, experiential values, and attitudinal values.
\end{abstract}

Keywords: polygamy, meaning, adjustments, marriage

\section{PENDAHULUAN}

Poligami, mendengar katanya saja sudah mengundang kontroversi. Terlebih lagi dari berbagai media terdengar kisah-kisah memilukan pada keluarga yang terkena dampak langsung poligami. Dampak-dampak yang biasanya terangkat oleh media tentunya dampak-dampak buruk dari berpoligami. Dampak-dampak buruk tersebut diantaranya; berkurangnya kepercayaan istri pada suami dan bertambahnya rasa curiga istri pertama terhadap suami, dan anakanak menderita lahir batin karena saling berebut kasih sayang, saling cemburu, saling curiga dan membenci, terjadinya ketidakadilan perhatian, cinta, dan pembagian harta, dan kemunduran ekonomi (Hambrah, 2006). Uraian kasus di atas menggambarkan bahwa ada sisi kehidupan yang mungkin tidak biasa bagi orang lain, atau bahkan ada 
yang memujinya luar biasa merupakan sisi kehidupan yang penuh dinamika. Seorang istri mengizinkan suaminya menikah lagi bukan tanpa pertimbangan atau latar belakang faktor yang mempengaruhinya hingga ia dapat memberi izin tersebut. Risiko dari perizinan tersebut pun telah ia pikirkan bahwa kelak suaminya memiliki istri lain tidak hanya dirinya. Ada cerita baru juga dalam rumah tangganya di hari kemudian dengan hadirnya orang baru. Penyesuaian terhadap kehidupan perkawinan poligami pun ia lakukan seperti yang tergambar pada uraian kasus di atas. Penerimaan terhadap kehadiran orang-orang baru (istri kedua, dan seterusnya) adalah bagian dari proses penyesuaian yang penuh dinamika.

Baik kalangan jurnalis maupun akademisi telah banyak yang mempublikasikan karya-karyanya yang berkenaan dengan kehidupan perkawinan poligami. Warna-warni dari karya-karya tersebut tergambar bahwa ada yang berpihak dan ada pula yang tidak berpihak pada poligami. Seperti yang terdapat pada hasil-hasil penelitian terkait kehidupan perkawinan poligami, diantaranya yang dilakukan oleh Multahada dan Widyastuti. Multahada (2005) melalui penelitiannya membuktikan bahwa mayoritas remaja yang ayahnya poligami mengalami kekerasan psikologis. Kekerasan psikologis tersebut menurunkan harga diri. Penalaran moral remaja yang ayahnya poligami pun terbilang rendah. Widyastuti (2002) juga telah meneliti bahwa harga diri remaja yang orangtuanya poligami lebih rendah dibandingkan dengan harga diri remaja yang orangtuanya monogami, dan tingkat depresi remaja yang orangtuanya poligami lebih tinggi daripada tingkat depresi remaja yang orangtuanya monogami.

Menurut Lianawati (2008) poligami terjadi karena seseorang tidak lagi berkomitmen pada aspekaspek struktural. Aspek-aspek struktural tersebut di antaranya adalah ada ketergantungan finansial dari pihak istri, memikirkan masa depan anak-anak, nama baik pribadi dan keluarga, birokrasi perceraian yang sulit, status janda yang negatif 
di mata masyarakat, dan sebagainya. Hal ini diduga menyebabkan istri menerima suami berpoligami. (Lianawati, 2008)

Menengok pada sejarah diturunkannya ayat-ayat yang berkenaan dengan poligami, bahwa di zaman nabi banyak janda-janda yang perlu disantuni dikarenakan suami mereka meninggal di medan perang, sehingga menikahi jandajanda juga merupakan solusi atas kehormatan masyarakat (Ad Dimasyqi, 2000). Lebih lanjut dijelaskan juga terjadinya poligami pada zaman Nabi tersebut tak terlepas karena situasi dan kondisi yang memaksa hal tersebut dilakukan demi melindungi perempuan dari segala bentuk penindasan.

Ajaran agama Kristen tidak membenarkan poligami (Matius 19: 6). Menengok pada sejarahnya, pernah dituliskan pada kitab perjanjian lama bahwa poligami memang pernah ada, terbatas pada raja-raja. Di kalangan masyarakat yang ada hanya monogami.

Pada ajaran Hindu ada dua penafsiran yang berbeda tentang poligami. Pandangan pertama membolehkan poligami, ajaran Hindu mengizinkan perkawinan hingga empat istri. Hal ini bercermin pada tradisi orang Bali tempo dulu, terutama para raja berkuasa. Poligami diistilahkan sama dengan "kresna atau kresna brahmacari". Putu Anggraeni menambahkan poligami yang terjadi di Bali itu diantaranya beralasan menghindari status janda. Sedangkan pandangan kedua, ajaran Hindu tidak membolehkan poligami. Poligami yang diizinkan pada ajaran Hindu pun, seperti karena tak punya keturunan atau karena sakit. Poligami dalam ajaran Hindu sejalan dengan UU perkawinan maupun PP nomor 10 tahun 1983 yang diperbaharui dengan PP nomor 45 tahun 1999, poligami boleh atas seizin istri pertama.

Negara Republik Indonesia dengan kekuatan hukumnya yang berlaku mengatur pula praktek poligami yang terdapat pada UU No. 1 tahun 1974 dalam pasal 3, 4, 5, dan pasal 65. Sekali pun peraturan perundang-undangan yang secara jelas mengatur praktek poligami agar suami dapat mempertimbangkan hal 
tersebut, para aktivis feminis, para penulis perempuan, dan sebagian tokoh agama menyatakan diri mereka menolak poligami, dapat dilihat di sekitar ada perempuan-perempuan yang justru bersedia atau mengizinkan suami dalam berpoligami. Hal ini tentunya sangat berseberangan dengan apa yang selama ini diperjuangkan oleh para perempuan pada umumnya. Oleh karena itu, sesekali beberapa perempuan tersebut mendapat protes dari orang-orang di sekitar mereka. Namun protes tersebut tidak mampu menggoyahkan niat mereka, mereka justru dapat saling mengakrabkan diri sesama istri dari satu suami.

Ada sederet nama yang cukup dikenal masyarakat umum, saat ini tengah menjalani kehidupan keluarga poligami. Dengan kata lain mereka menerima suami mereka untuk berpoligami. Mereka pun melakukan penyesuaian dengan kehidupan perkawinan poligami. Dickson (2007) menguraikan berapa fakta, masalah poligami, seperti: Rini Purwanti, istri pertama Puspo Wardoyo, mengakui menangis ketika pertama kali suami berpoligami.
Pada kali berikutnya, Rini Purwanti telah mampu membantu suami melamarkan istri ketiga bagi suaminya. Ninih, istri pertama Aa Gym, mengakui merasa sedih dan kaget ketika suami mau berpoligami. Kemudian pada kesempatan berikutnya, Ninih dapat berbagi peran rumah tangga dengan istri kedua Aa Gym Inilah contoh dua perempuan yang sudah sangat dikenal melalui media, mereka menjalani hidup dengan status sebagai istri pertama dari suami mereka.

Perempuan ikut mengambil peran dalam menentukan terbentuknya perkawinan poligami, yaitu bersedia menjadi istri pertama, kedua, dan seterusnya. Menurut hasil penelitian Rustanti (2004) perempuan yang bersedia dipoligami memiliki beberapa alasan, diantaranya ketergantungan materi (perempuan tidak bekerja), pengaruh daya tarik fisik dan keterikatan.

Hasil penelitian juga menjelaskan bahwa poligami terjadi juga tidak terlepas dari adanya faktor penyebab hingga suami melakukannya. Ada beberapa faktor yang menyebabkan 
suami berpoligami, yaitu pertama, suami merasa tidak diperhatikan oleh istrinya. Pada dasarnya seorang suami sudah terbiasa dilayani oleh istri sehingga apabila tidak dilayani karena beberapa alasan maka suami merasa tidak diperhatikan. Kedua, yaitu istri menolak hubungan intim karena capek setelah bekerja seharian juga membuat suami merasa ditolak dan merasa tidak diperhatikan. Ketiga, istri tidak dapat melahirkan keturunan. Keempat, istri memiliki penyakit kronis. Kelima, suami merasa mampu secara material dan spiritual sehingga poligami dilakukan untuk menghindarkan diri dari perbuatan zinah. Keenam, suami sering bepergian, dinas ke luar kota, bekerja berpindah-pindah, atau tinggal di kota terpisah.

Dari uraian di atas dapat disimpulkan bahwa perkawinan poligami terjadi tidak terlepas dari keterlibatan antara keduanya yaitu suami dan istri, apapun alasannya. Praktek poligami telah diatur secara jelas dalam agama dan perundangundangan Negara Republik Indonesia. Masyarakat ada yang menyatakan diri pro dan kontra terhadap perkawinan poligami. Para istri yang bersedia dan menyesuaikan dengan suaminya yang berpoligami, memiliki konsep tentang makna penyesuaian bagi mereka. Oleh karena itu menarik untuk digali lebih mendalam tentang makna penyesuaian bagi istri yang suaminya berpoligami, dan mengamati proses penyesuaian mereka.

Beberapa pertanyaan yang akan diungkap dalam tulisan ini adalah:

1. Apa makna penyesuaian bagi istri pertama yang suaminya berpoligami

2. Bagaimana proses penyesuaian istri pertama yang suaminya berpoligami?

3. Bagaimana pengalaman emosi dalam proses penyesuaian istri pertama yang suaminya berpoligami?

4. Bagaimana pengalaman beragama dalam proses penyesuaian istri pertama yang suaminya berpoligami?

5. Bagaimana dukungan keluarga dalam proses penyesuaian istri pertama yang suaminya berpoligami? 
Tujuan penelitian adalah: psikologis penyesuiaan tersebut. mengetahui makna penyesuaian bagi istri pertama yang suaminya berpoligami, menjelaskan proses penyesuaian istri pertama yang suaminya berpoligami, mengungkap pengalaman emosi dalam proses penyesuaian istri pertama yang suaminya berpoligami dan pengalaman beragama dalam proses penyesuaian istri pertama yang suaminya berpoligami, mengetahui dukungan keluarga dalam proses penyesuaian istri pertama yang suaminya berpoligami

\section{METODE PENELITIAN}

\section{Desain Penelitian}

Penelitian ini menggunakan desain penelitian kualitatif dengan pendekatan studi kasus kolektif, dengan alasan pembahasan tentang makna penyesuaian bagi istri pertama yang suaminya berpoligami adalah sesuatu yang unik, dan lebih spesifik bukan fenomena yang terjadi pada kebanyakan orang pada suatu masa tertentu, untuk dieksplorasi dalam rangka memaknai dinamika

Sebagaimana studi kasus merupakan sebuah pendekatan dalam penelitian psikologi yang tidak mencoba mengumpulkan informasi dari jumlah partisipan yang banyak (Hayes, 2000).

Sumber data yang digunakan dalam penelitian ini meliputi empat hal, antara lain:

1) Subyek penelitian

Subyek dalam penelitian ini adalah perempuan, istri pertama dari suami yang mempunyai istri lebih dari satu, memiliki anak dari perkawinan pertama, istri pertama memiliki penghasilan sendiri, usia perkawinan poligami minimal 3 tahun. Hal ini didasarkan pada hasil penelitian Burgess \& Cottrell (dalam Landis \& Landis, 1960) bahwa pasangan membutuhkan waktu sekurangnya 2-4 tahun hingga pasangan tersebut dapat menyesuaikan dalam perkawinan yang sedang dijalaninya.

Penelitian ini melibatkan sekurang-kurangnya 3 orang perempuan. Rentang usia subyek antara 40 tahun hingga 70 tahun. Hal ini didasarkan pada bahwa menurut 
Santrock (2002), orang pada usia ini termasuk pada tugas perkembangan dewasa pertengahan hingga dewasa akhir. Pengalaman emosi pada masa ini lebih kompleks, transisi paruh kehidupan berlangsung hiruk pikuk dan secara psikologis menyakitkan, karena banyak aspek kehidupan dipertanyakan. Menurut Levinson (dalam Santrock, 2002), keberhasilan transisi paruh kehidupan terletak pada seberapa efektif orang mengurangi sifat-sifat berlawanan dan menerima masing-masing dari mereka sebagai bagian integral dari keberadaanya.

2) Informan

Selain ada subyek dalam penelitian ini, dibutuhkan pula informan. Informan penelitian ini tergolong menjadi dua, yaitu informan pelaku dan informan tahu (Koentjoro, 2007). Informan pelaku merupakan orang-orang yang terlibat dekat dengan subyek, terkena dampak langsung dan tidak langsung. Informan pelaku yang dimaksud adalah suami, istri-istri lainnya, anak-anak, dan saudara kandung. Informan tahu adalah orang-orang di sekitar subyek yang hanya mengetahui informasi tentang subyek. Informan tahu yang dimaksud adalah teman subyek, tetangga subyek, ketua RT, pamong masyarakat setempat, dan seterusnya yang dapat memberikan informasi guna kelengkapan data penelitian.

3) Dokumen tertulis; data sekunder

Dokumen yang digunakan sebagai sumber data penelitan ini antara lain surat-surat pernyataan, surat-surat keterangan, catatan harian (diary), atau surat-surat pribadi, fotofoto yang berkenaan dengan kehidupan keluarga poligami subyek. 4) Dokumen tidak tertulis; Metafor

Dalam penelitian ini, metafor penting untuk dipahami dalam rangka menghindari terjadinya bias pada hasil penelitian, sebab subyek mungkin saja menampak bahasa tubuh atau emosi yang berbeda dengan apa yang diucapkannya ketika proses wawancara berlangsung

Data-data yang diperlukan dalam penelitian ini akan dikumpulkan melalui dua cara, yaitu observasi dan wawancara.

1) Observasi 
Dalam penelitian ini, subyek di depan umum dengan yang observasi dilakukan secara dikatakannya ketika diwawancara, partisipan, peneliti terlibat langsung membandingkan apa yang dikatakan dalam kegiatan rumah atau kegiatan sehari-hari subyek di lokasi penelitian. Hal ini dilakukan dengan tujuan agar memperoleh informasi sebanyak-banyaknya baik yang bersifat metafor atau deskripsi.

\section{2) Wawancara}

Dalam penelitian ini, tipe wawancara yang digunakan adalah The Depth Interview, di mana rapport terus dibangun dan kepercayaan dibentuk agar subyek yang diwawancara terus mengeksplor dirinya lebih mendalam dan terdapat motivasi yang kuat dalam diri subyek. Wawancara akan dilakukan secara terpisah pada subyek, informan pelaku dan informan tahu.

Untuk menilai keabsahan data penelitian ini, peneliti juga menggunakan metode triangulasi. Triangulasi yang akan diaplikasikan pada penelitian ini, diantaranya: triangulasi dengan sumber (membandingkan hasil pengamatan dengan hasil wawancara, orang-orang tentang situasi penelitian dengan apa yg dikatakan subyek sepanjang waktu), triangulasi dengan metode (pengecekan derajat kepercayaan penemuan hasil penelitian dengan kedua teknik pengumpulan data yaitu observasi \& wawancara) (Moleong, 2008).

Dalam menganalisi data, peneliti melakukan coding dengan ketiga bentuknya. Pertama, open coding; menguraikan hasil temuan, memberi kode pada tiap penemuan, hingga temuan-temuan dapat disusun dalam sebuah tema. Kedua, axial coding; mengelompokkan tema-tema yang sudah ada ke dalam sebuah kategori. Ketiga, selective coding; mengelompokkan kategori-kategori tadi ke dalam sebuah alur pikir sehingga memunculkan teori baru. Selective coding ini pun terbagi dua macam yaitu selective coding inclusive; bila data yang dibutuhkan masih kurang, maka terus mencari lagi. Selective coding exclusive; data yang sudah ada bisa saja dibuang bila membandingkan apa yang dikatakan 
dirasa kurang mengena (Koentjoro, 2007).

Secara lebih rinci, StevickColaizzi- Keen mengajukan prosedur analisis dan interpretasi data dengan metode modifikasi, dengan langkah sebagai berikut (Moustakas, 1994):

1. Mempertimbangkan masingmasing pernyataan mengenai pentingnya gambaran pengalaman

2. Mencatat semua pernyataan yang sesuai dengan tema penelitian

3. Membuat daftar pernyataan yang tidak berulang dan tidak tumpang tindih. Pernyataan-pernyataan ini merupakan horizon yang sama atau unit makna yang sama dari pengalaman

4. Menghubungkan

dan mengelompokkan unit makna yang sama ke dalam tema-tema

5. Mensintesakan unit makna dan tema-tema yang sama ke dalam deskripsi tekstural dari pengalaman dan juga memasukkan contoh verbatim

6. Merefleksikan data ke dalam deskripsi tekstural penulis. Dengan menggunakan imaginative variation, kemudian membuat deskripsi struktural dari pengalaman
7. Membuat gambaran teksturalstruktural dari makna dan esensi pengalaman

8. Melakukan langkah 1 sampai 7 untuk pengalaman masing-masing subyek

Dari gambaran teksturalstruktural individu dari semua pengalaman masing-masing subyek, dibuat gabungan deskripsi makna dan esensi dari tekstural- struktural dari pengalaman, dan dibuat juga penggabungan semua gambaran tekstural- struktural individu ke dalam gambaran yang universal dari pengalaman yang merepresentasikan kelompok secara keseluruhan.

\section{HASIL}

\section{A. Makna penyesuaian}

Pemaknaan ini kemudian berkait dengan bagaimana masing-masing subyek memaknai penyesuaian dengan suami mereka yang berpoligami. Oleh karena masingmasing subyek memaknai kehidupan perkawinan poligami yang dijalani mereka dengan menyandarkan pada ketentuan Tuhan, maka makna penyesuaian bagi mereka adalah hidup dengan mendapat keridhoan 
dari Tuhan, melakukan berbagai kegiatan keagamaan, bahkan semakin meningkatkan keimanan, dan sarana untuk semakin mendekatkan diri dengan Tuhan.

\section{B. Proses penyesuaian}

Subyek membutuhkan waktu kurang lebih 1 tahun untuk penyesuaian. Untuk mengetahui proses penyesuaian masing-masing subyek hingga saat ini, dapat dilihat bagaimana subyek mengungkapkan alasan mampu menjalani kehidupan perkawinan poligami. Alasan-alasan tersebut berkenaan dengan tujuan akhir dari perjalanan hidup, cara pandang terhadap suatu masalah, dan bagaimana subyek menggambarkan dirinya memiliki kesabaran dalam menghadapi suatu masalah.

Kondisi terakhir saat peneliti mewawancarai masing-masing subyek, kehidupan perkawinan poligami mereka berjalan harmonis, silaturahmi antara istri pertama dan kedua terjalin baik, saling melengkapi dan saling memperhatikan.

\section{Pengalaman emosi dalam penyesuaian}

Proses penyesuaian masingmasing subyek tidak terlepas dari pengalaman emosi yang dialami masing-masing subyek. Pengalaman emosi ini terlihat sejak awal ketika suami masing-masing subyek meminta izin hendak berpoligami. Masing-masing subyek mengalami perasaan sedih ketika suami meminta izin, namun masing-masing subyek berusaha mengendalikan emosi mereka. Hal ini didasarkan pada adanya rasa sayang pada suami, rasa kasihan pada suami, dan rasa ingin menghargai suami dan dihargai.

Memasuki tahap awal tahun perkawinan poligami, masingmasing subyek memiliki pertimbangan dalam menyesuaikan dengan suami yang berpoligami, yang melibatkan juga pengalaman emosi. Masing-masing subyek merasa rendah diri (merasa sudah tua), merasa malu, dan menghindarkan diri dari keributan.

Tahap selanjutnya pada proses penyesuaian ini, masing-masing subyek juga mengungkapkan bahwa mereka juga pernah mengekspresikan emosi marah, 
kesal, sedih, dan merasa penyesuaiannya. Ketiga subyek telah dikesampingkan oleh suami.

Menjelaskan kondisi psikologis masing-masing subyek dalam penyesuaian, selain mengamati pengalaman emosi dan hal-hal yang dipikirkan oleh subyek, dapat diamati pula sikap dan perilaku subyek dalam penyesuaian. Subyek 1 bersikap \& berperilaku terbuka, suka menolong, dan tegas terutama dalam menegakkan kebenaran. Subyek 2 bersikap mengalah, berperilaku mengayomi, mengerti, dan memberi perhatian pada suami. Subyek 3 Bersikap diam, berperilaku tidak banyak bicara, berusaha ikhlas, dan berusaha menyenangkan hati orang.

\section{Pengalaman beragama dalam penyesuaian}

Sebagaimana makna hidup dapat bersumber dari experiential values, yaitu keyakinan dan penghayatan akan nilai-nilai kebenaran, kebajikan, keindahan, keimanan, dan keagamaan, serta cinta kasih (Bastaman, 2007), maka dalam mengamati makna penyesuaian istri yang suaminya berpoligami, diamati pula pengalaman beragama masingmasing subyek dalam memiliki bekal beragama dari kecil, dari kedua orangtua mereka. Dengan demikian rutinitas beragama telah dijalani sejak dahulu, hingga saat ini mengalami peningkatan.

Berkaitan dengan pengalaman beragama dalam penyesuaian, ada prinsip-prinsip/nilai-nilai yang dipegang oleh masing-masing subyek. Subyek 1 memegang prinsip bahwa taat pada suami, mau dimadu, sabar, ikhlas kelak jaminannya mendapatkan surga di akhirat, sebagaimana yang sering terdengar melalui pengajian agama. Subyek 2 memegang prinsip menjadi hamba terbaik, menjadi tauladan, sabar, ikhlas, selalu bersyukur dalam menjalani hidup dalam kondisi apapun. Subyek 3 memegang prinsip kesabaran dan keikhlasan dalam menerima kondisi, serta tawakal pada Allah dalam menjalani kehidupan perkawinan poligami ini.

\section{E. Dukungan keluarga dalam penyesuaian}

Dukungan keluarga dalam penyesuaian menjadi faktor penting dalam proses penyesuaian (Cobb dalam dalam Rice, 1999), begitu pula 
pada penyesuaian istri yang suaminya berpoligami. Dukungan keluarga yang dimaksud di sini adalah suami meminta izin pada istri, suami membagi waktu dan perhatian, komunikasi istri dan suami terus berlangsung, anak-anak ikut mendukung dengan memberi perhatian pada ibu mereka, serta keluarga dekat subyek memberi perhatian pula pada subyek kaitannya dengan kehidupan perkawinan poligami.

\section{PEMBAHASAN}

Penyesuaian bukan hanya proses intelektual, namun merupakan aktivitas yang bersifat menyesuaikan, melibatkan pengalaman emosi, seperti emosi stress marah, takut, cemas, merasa bersalah dan merasa malu (Lazarus, 1961). Penyesuaian, kuncinya terletak pada perjuangan memaknai sesuatu, yang tidak ada pilihan bebas dan pilihan tanggung jawab (Frankl, dalam Calhoun, 1990). Istri (subyek) yang mampu memaknai bagaimana penyesuaian yang dijalani dengan suami yang berpoligami, dengan demikian istri telah memegang kunci penyesuaian.
Subyek yang mengakui bahwa dalam penyesuaiannya dengan suami yang berpoligami terdapat pengalaman emosi yang berdinamika, kadang senang, tenang, bahagia, kadang kesal, sedih, merasa rendah diri, merasa malu, mengalami emosi yang turun-naik, tidak stabil, dengan demikian sesuai dengan pengetian penyesuaian menurut Lazarus.

Menurut Degenova \& Philip (2005) penyesuaian perkawinan merupakan proses memodifikasi, menyesuaikan, dan mengubah perilaku yang individualis menjadi perilaku berpasangan dan berinteraksi secara maksimal, sebuah proses dinamis, proses yang berjalan terus menerus berlangsung salam keseluruhan perkawinan Penyesuaian perkawinan poligami pada subyek, subyek menunjukkan mampu memodifikasi dan mengubah perilaku yang semula berstatus istri tunggal (suami hanya milik dirinya sendiri), menjadi berstatus istri pertama (suami juga milik istri lainnya), dengan bersikap dan berperilaku perhatian, sayang, dan menghargai suami dan istri kedua. 
Dinamika pengalaman emosi subyek dalam penyesuaian dengan suami yang berpoligami, terjadi turun-naik yang kadang terjadi tibatiba ataupun sebelumnya menggejala, atau biasa disebut didahului stressor seperti yang diungkapkan Sarafino (1997). Life transition pada subyek melibatkan pengalaman emosi, dengan adanya status baru pada kehidupan perkawinannya, terbaginya kasih sayang dan perhatian suami subyek, dan penambahan anggota keluarga baru. Oleh karenanya, sesekali subyek merasa sedih, merasa rendah diri, merasa malu, merasa cemas, marah ataupun kesal dalam masa penyesuaian. Terlebih lagi pada tahun pertama kehidupan perkawinan poligami subyek, dinamika pengalaman emosinya begitu terlihat, kadang mampu mengungkapkan bahwa dirinya menerima takdir, sabar dan ikhlas, di lain waktu kadang menunjukan perilaku kesal dan marah. Pengalaman emosi ini dapat pula terus terjadi, atau dapat pula subyek telah sedikit demi sedikit belajar mengendalikan emosi.
Subyek memaknai penyesuaian mereka dengan suami yang berpoligami, atau dalam kehidupan perkawinan poligami, adalah menjalaninya dengan tidak banyak menuntut, bersyukur dengan nikmat yang ada. Kehidupan yang dijalani subyek saat ini adalah jalan menuju kedekatan diri dengan sang Pencipta, dan jalan pengabdian kepada Allah Subhannahu Wa Ta'ala.

Makna penyesuaian subyek bersumber pula dari ketiga sumber makna hidup menurut Frankl (dalam Bastaman, 2007), yaitu creative values, experiential values, dan attitudinal values. Subyek mampu berkarya, bekerja, serta melaksanakan tugas dan kewajiban dengan penuh tanggung jawab, cerminan creative values. Subyek bersikap sabar dan ikhlas dalam menjalani kehidupan perkawinan poligami, cerminan attitudinal values. Subyek meyakini bahwa kehidupan yang dijalaninya saat ini adalah anugerah, takdir dari Allah, mengimaninya dengan meningkatkan rutinitas beragama, serta memelihara cinta kepada anak-anak dan suaminya. 


\section{KESIMPULAN DAN SARAN}

\section{Kesimpulan}

Makna penyesuaian bagi istri yang suaminya berpoligami dapat ditemukan dalam penyesuaian itu sendiri. Makna penyesuaian bagi istri yang dimaksud di sini adalah menjalaninya dengan tidak banyak menuntut, bersyukur dengan nikmat yang ada. Kehidupan yang dijalani saat ini adalah jalan menuju kedekatan diri dengan sang Pencipta, dan jalan pengabdian kepada Allah Subhannahu Wa Ta'ala.

Makna penyesuaian bagi istri yang suaminya berpoligami bersumber dari creative values, experiential values, dan attitudinal values. Untuk dapat mengimprovisasi makna penyesuaian tersebut dibutuhkan niat, potensi diri, tujuan, usaha, metode, sarana, lingkungan, asas-asas sukses dan ibadah (doa).

Proses penyesuaian istri yang suaminya berpoligami berkaitan dengan waktu yang dibutuhkan untuk memasuki life transition, kesiapan atau kemampuan yang dimiliki dalam menjalani kehidupan, ungkapan perasaan yang dialami saat ini, dan hal-hal yang berkenaan dengan proses pengalaman mencapai keadaan saat ini (kondisi terakhir dilakukannya penelitian). Istri membutuhkan waktu kurang lebih satu tahun hingga dapat menerima suami berpoligami. Proses penyesuaian istri membutuhkan kemampuan bersabar, berpikiran positif, serta pandai bersyukur. Saat terakhir penelitian ini, istri pertama mengungkapkan perasaan tenang, senang, dan bahagia dengan kehidupan yang dijalaninya saat ini, setelah melalui berbagai pengalaman bersama istri kedua, anak-anak dan suami.

Pengalaman emosi istri pertama dalam penyesuaian dengan suami yang berpoligami terjadi dengan penuh dinamika, sesekali menunjukan ekspresi emosi marah, kesal, cemas, merasa bersalah, namun sesekali pula menunjukan ekspresi emosi senang, tenang, bahagia. Hal ini terlihat dari ungkapan istri pertama ketika diwawancara, dan metaphor yang menyertai ungkapan tersebut, seperti mata berkaca-kaca, menahan nafas, 
mengelus dada, tidak berani menatap lawan bicara, tertawa, senyum, dan terharu.

Pengalaman beragama istri pertama dalam penyesuaian dengan suaminya yang berpoligami, terjadi peningkatan, rutinitas beragama terus berjalan, bahkan mampu memimpin kegiatan keagamaan, dan amalan sunnah semakin sering dilakukan.

Istri pertama yang suaminya berpoligami mendapat dukungan sosial dari anggota keluarganya, seperti anak-anak, suami, dan istri kedua, serta mendapat dukungan moril pula dari keluarga dekat, seperti saudara kandung, saudara ipar, mertua, dan saudara jauh, serta tetangga sekitar.

\section{Saran}

Penelitian tentang kehidupan perkawinan poligami ini lebih banyak bersifat mengungkap masa lalu subyek, daripada apa yang terjadi saat ini. Pengungkapan masa lalu terkait dengan memori subyek, kemampuan mengingat apa yang dahulu terjadi. Tidak jarang subyek akan mengalami lupa, sulit mengingat kejadian-kejadian terdahulu. Oleh karenanya, dibutuhkan keterampilan yang lebih dalam diri peneliti untuk membantu subyek mengingat kembali kejadiankejadian terdahulu, dengan lebih variatif menggunakan bahasa-bahasa yang dapat menstimulus subyek, atau teknik tertentu yang dapat membantu subyek dalam memanggil kembali ingatannya terhadap suatu kejadian di masa lalu.

Penelitian yang terkait dengan kehidupan keluarga, terlebih lagi bila berkaitan pengalaman emosi atau sesuatu kejadian yang dahulu pernah menyakitkan, sangat rentan terjadi bias dari informasi-informasi yang diberikan subyek kepada peneliti, atau dapat pula sulit mengungkapnya dikarenakan subyek tidak ingin mengingat atau membuka kembali luka lama tersebut. Menghadapi hal ini, peneliti harus memiliki keberanian (bravery), menjauhkan diri dari rasa segan, sebab pengungkapan kejadian yang bersifat demikian membutuhkan banyak kedekatan dengan lebih banyak membangun rapport dengan subyek hingga subyek dengan sendirinya 
dapat mengungkap pengalaman emosi yang dialaminya dahulu.

Bagi peneliti selanjutnya yang tertarik untuk meneliti penyesuaian dalam perkawinan poligami disarankan mengambil subyek penelitian lebih spesifik dalam hal usia perkawinan poligami lebih lama, misal 5 tahun ke atas atau juga subyek dengan poligami yang saat di usia perkawinan tertentu, misal pada masa middle adulthood.

Peneliti selanjutnya juga diharapkan untuk menggunakan metode penelitian lain untuk mendapatkan penemuan baru terkait dengan kehidupan perkawinan poligami yang berbeda.

\section{DAFTAR PUSTAKA}

Ad Dimasyqi, Al Imam Abul Fida Ibnu Katsir. 2000. Tafsir Ibnu Katsir Juz 18. (Alih bahasa: Bahrun Abu Bakar). Penerbit Sinar Baru Algensindo. Bandung

Bastaman, Hana Djumhana. 2007. Logoterapi: psikologi untuk menemukan makna hidup dan meraih hidup bermakna. Penerbit Rajawali press. Jakarta
Calhoun, James F. 1990. Psychology of Adjustment \& Human Relationships. Edisi ketiga. Penerbit McGraw Hill Publishing Company. New York

Degenova, Mary K \& Rice, F. Philip. 2005.

Intimate Relationship, Marriages \& Families. Edisi 6. Penerbit McGraw Hill. Boston

Dickson, Anne Louis. 2007. Pandangan ibu-ibu 'Aisyiyah di malang terhadap poligami. Fakultas Ilmu Sosial dan Ilmu Politik. Universitas Muhammadiyah. Malang

Hambrah. 2006. Dampak buruk poligami beserta contoh kasus.

www.indonesia.faithfreedo m.org. diupdate tanggal 21 oktober 2008

Hayes, Nicky. 2000. Doing psychological research. Penerbit Open University Press. Buckingham

Koentjoro. 2007. Bahan kuliah metodologi penelitian kualitatif. $\quad$ Fakultas Psikologi UGM. Yogyakarta

Landis, Judson T. \& Landis, Mary, G. 1960. Personal Adjustment, Marriage \& Family Living. Penerbit Prentice Hall, Inc. New York 
Lazarus, Richard S. 1961. Patterns of Adjustment. Penerbit McGraw-Hill Kogakusha, LTD. Tokyo

Lianawati, Ester. 2008. Reduksi seksualitas dan poligami dalam UU perkawinan. www.esterlianawati.wordpr ess.com. Diupdate tanggal 21 oktober 2008

Moleong, Lexi J. 2008. Metodologi Penelitian Kualitatif. Penerbit Remaja Rosdakarya. Bandung

Moustakas,

C. 1994.

Phenomenological research methods. Penerbit Sage publication, Inc. California

Multahada, Erna. 2005. Kekerasan psikologis, harga diri dan penalaran moral remaja dari keluarga dengan ayah poligami. Tesis. Fakultas Psikologi UGM. Yogyakarta

Rice, Philip L. 1999. Stress and Health. Edisi 3. Penerbit Brooks/Cole Publishing Company. USA

Rustanti, Herlina. 2004. Tinjauan psikologis pernikahan poligami dari sudut pandang suami. Laporan praktek kerja lapangan bidang psikologi sosial. Program Profesi Psikologi. Fakultas Psikologi UGM. Yogyakarta

Santrock, John W. 2002. Life Span Development: perkembangan masa hidup. (Alih bahasa: Juda Damanik \& Achmad Chusairi). Edisi kelima. Penerbit Erlangga. Jakarta

Sarafino, Edward P. 1997. Health Psychology:

Biopsychosocial

Interaction. Edisi 3. Penerbit John Willey \& Sons, Inc. New York

Tim Redaksi. 2007. UndangUndang Republik Indonesia Nomor 1 Tahun 1974 Tentang Perkawinan \& Kompilasi Hukum Islam. Penerbit Citra Umbara. Bandung

Widyastuti. 2002. Peran status perkawinan poligami dan monogami orang tua terhadap harga diri, koping, dan depresi. Tesis. Fakultas Psikologi UGM. Yogyakarta 